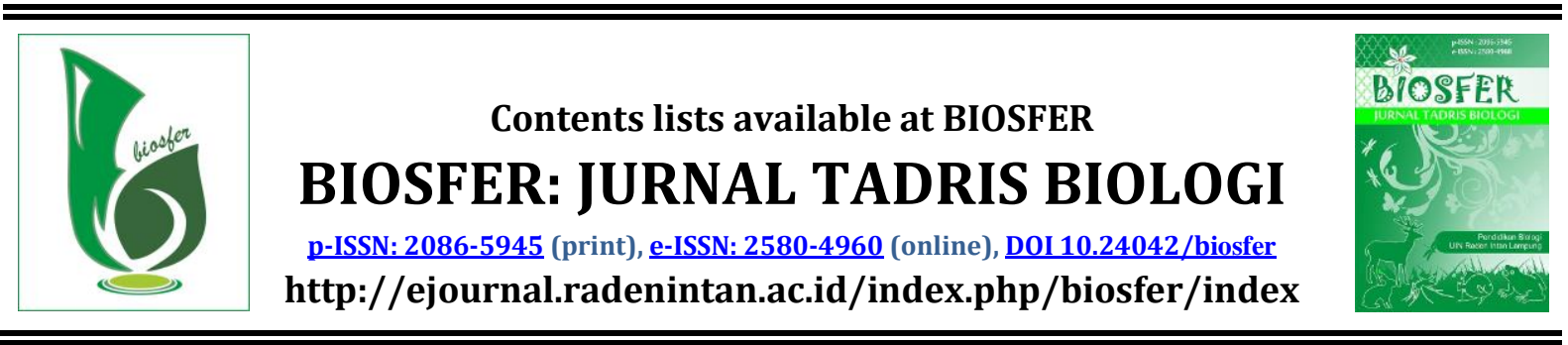

\title{
The Influence of Acacia Parasite Filtrate as Bioinsecticide for Bagworms (Methane Plana)
}

\author{
Makmun Murod $^{1 *}$, Cicik Ainurrohmah², Hayatin Nufus ${ }^{3}$ \\ 1, 2, 3 Department of Biology, Faculty of Mathematics and Natural Sciences, Surabaya State University, \\ Indonesia
}

\section{ARTICLE INFO}

\section{Article History}

Received: April 18 $18^{\text {th }}, 2020$

Accepted: May 11th 2020

Published: June $30^{\text {th }}, 2020$

Keywords:

Averrhoa bilimbi L.;

Sansevieria trifasciata P.;

Eggs of Pomacea canaliculata

L.

*Correspondence Address:
makmunmurod03@gmail.com

\section{ABSTRACT}

Dendrophthoe pentandra is a plant parasite that can be detrimental to the host plant and attacks various types of trees, such as acacia. The purpose of this study was to examine the effects and determine the concentration of acacia parasite filtrate on bagworms. This research was an experimental study which used $0 \%, 20 \%, 40 \%, 60 \%, 80 \%$, and $100 \%$ parasite filtrate concentrations. The study employed the Completely Randomized Design method with ANOVA as the method of analysis. Based on the results of phytochemical tests, the parasite filtrate contained alkaloids, flavonoids, saponins, triterpenoids, phenolics, and tannins. The ANOVA test results showed that the concentration of acacia parasite filtrate affected the mortality of the bagworms. Furthermore, based on Duncan's test, the most effective concentrations to be applied were $80 \%, 60 \%$, and $100 \%$.

\section{Pengaruh Filtrat Benalu Akasia Sebaga Bioinsektisida Ulat Kantong (Metisa Plana)}

\begin{abstract}
Abstrak: Benalu (Dendrophthoe pentandra) merupakan parasit tanaman yang dapat merugikan bagi tanaman yang menjadi inangnya, dan menyerang berbagai jenis pepohonan seperti akasia. Tujuan penelitian ini untuk menguji pengaruh dan menentukan konsentrasi filtrat benalu terhadap hama ulat kantong. Penelitian ini merupakan eksperimental yang menggunakan perlakukan konsentrasi filtrat daun benalu yaitu 0\%, 20\%, 40\%, 60\%, 80\%, dan 100\%. Penelitian menggunakan metode RAL (Rancangan Acak Lengkap) dengan analisis menggunakan ANOVA (Analisis Varian). Berdasarkan hasil uji fitokimia daun benalu memiliki kandungan meliputi: alkaloid, flavonoid, saponin, triterpenoid, fenolik dan tanin.Hasil uji Anova menunjukkan bahwa konsentrasi filtrat benalu berpengaruh terhadap mortalitas ulat kantong. Berdasarkan hasil uji Duncan menunjukkan bahwa konsentrasi yang paling efektif adalah konsentrasi 80\%, 60\% dan 100\%.
\end{abstract}




\section{INTRODUCTION}

Biodiversity of tropical forests is beneficial for the environmental, social, and economic life of the community (Kurniawan dkk., 2020; Nahdi, 2008; Ridhwan, 2012; Winarni dkk., 2018), by utilizing the plants as medicines (Nugroho, 2017; Nurjanah dkk., 2019; Purwantini, 2016). Bioinsecticides is the dry weight of chemicals (M. S. Lestari dkk., 2016; Saenong, 2016; Santosa, 2013). Bioinsecticides act as indicators of the potential of an ecosystem and forest productivity (Latumahina dkk., 2015). Bioinsecticides can be divided into trees bioinsecticide and underground biomass such as roots and litter mixed with the soil (Priono, 2013).

Bagworm (Metisa plana) damage plants by eating plant leaves for their body development and the formation of their bags (Sembiring dkk., 2013; Soesatrijo, 2018a). The bagworms' larvae like to consume the upper parts of leaves and use the lower parts of leaves to hang and form their bags (Sembiring dkk., 2013; Soesatrijo, 2018a). The damage on the plants can be seen clearly when the defoliation reaches 50\% (Affandi dkk., 2014; Lukmana \& Elafia, 2017; Soesatrijo, 2018b). Damage at this level will reduce yields by up to 10 tons of FFB/ha (Nugraheni \& Pangaribuan, 2008; Styarini dkk., 2011). Many plantations have reported a considerable loss due to the attacks of various types of bagworms (Haryati \& Nurawan, 2017; Soetopo \& INDRAYANI, 2015). Two years after the insects invade, palm oil productivity will generally decline quite sharply from $30 \%$ up to $40 \%$ (Susanto dkk, 2015). The attack caused by the bagworms (Metisa plana) will make the leaves look like they are on fire (Efendi dkk., 2020; Wahyuni \& Sinaga, 2017a). The larval instar feeds on the epidermis parts
(Susanto dkk., 2010; Wahyuni \& Sinaga, 2017b).

The bagworm (Metisa plana) is one of the pests that are damaging the plants by eating the leaf. The bagworms are found mainly on acacia trees in a plantation (Candra dkk., 2018; Utami \& Kurniawan, 2019). The larvae of the bagworms eat leaves to hang and form their bags (Soesatrijo, 2018). However, biopesticides can be utilized to control the parasite. This study was aimed to determine the effects of acacia parasite filtrate and the most optimal concentration to combat the bagworms (Metisa plana).

Based on the results of research by (Sopi \& Tallan, 2019) some plants have the potential to be anti-malaria, such as limestone, piper, parasite, and jack fruit. Loranthus is a plant parasite that can harm the host plant and attack various types of trees such as mango, starfruit, acacia, and guava. Based on research results conducted by (Uji, 2010), parasites can be easily found in the Syzygium. Loranthus is a plant that has potential as a medicinal herb derived from semi-parasitic plants (Nugraheni \& Pangaribuan, 2008; Sembiring dkk., 2013; Styarini dkk., 2011) Based on the results of research by (Sopi \& Tallan, 2019), the Loranthus contains alkaloids, saponins, flavonoids, quercetin, meso-inositol, rutin, and tannin. The content of secondary metabolites can be used as toxic in the form of bioinsecticide. Based on research conducted by (Wongkar dkk., 2015), high concentrations of alkaloids present in the parasite leaves are toxic for Artemia salina larvae. Research conducted by (Anita dkk., 2014) showed that the guava parasite contains alkaloids, flavonoids, and steroids that function as a bactericide. The alkaloid found in the Loranthus has the potential to be used as 
bioinsecticide to control the bagworms.

\section{METHOD}

This research employed the Completely Randomized Design with ANOVA as the data analysis method. The research was carried out at the Ecology Laboratory of Biology Department, Faculty of Mathematics and Natural Sciences, Surabaya State University for 6 months, from May to October 2019. The phytochemical testing on alkaloids, phenolics, flavonoids, saponins, tannins were carried out at the Organic Laboratory of Chemistry, Surabaya State University.

The materials for the research on the acacia parasite filtrate on bagworms were obtained from the East Java Fiber Crops Research Institute (Balittas). The research materials used were $5 \mathrm{~kg}$ of acacia parasite leaves and 10 liters of distilled water. The tools needed for this research were blenders, Erlenmeyer flask, electric scales, measuring cups, Petri dishes, and bowls. The research performed manipulations in the form of acacia parasite filtrate concentration, control treatments, the number of bagworms, the numbers of $0 \%$ concentration spraying, and treatments' responses in the form of bagworm mortality.

The bagworms samples were obtained from the Malang Sweetener and Fiber Crops Research Institute (Balittas). The bagworms samples were taken and then placed in a container for acclimatization and continued treatments. The sample of parasite leaves was taken from acacia. The acacia parasite leaf filtrate was made by using the tip of young parasite leaves which were then washed thoroughly using running water. The leaves were then drained, dried, and crushed into 500 grams powder. Five hundred $\mathrm{ml}$ of sterile distilled water was poured into the powder and then the mix was placed into sterile gauze to be squeezed so that the water from the sterile gauze containing the parasite leaf filtrate can be extracted (Suhaillah and Fuadah. 2017). The filtrate was then diluted with distilled water using the formula: $\mathrm{M}_{1} \times \mathrm{V}_{1}=\mathrm{M}_{2} \times \mathrm{V}_{2}$. The concentrations obtained were $20 \%$, $40 \%, 60 \%, 80 \%, 100 \%$, and $0 \%$ (as the control).

This research employed the Completely Randomized Design with one treatment factor, namely the concentration of acacia parasite leaf filtrate. The filtrate consisted of six variations, namely concentrations of $20 \%, 40 \%, 60 \%, 80 \%, 100 \%$, and $0 \%$ (as control). One experimental unit used five bagworms with five replications, so a total of 300 bagworms were needed. The method used was the combination of the residual method on the leaves and the insect contact/spraying method. Three leaves were used as feeds in each treatment replication. The surface of the leaves was smeared with the filtrate and the rest was sprayed on the tested larvae. The larvae had been fed by the treatment leaves for 72 hours and then they were fed fresh leaves. The experiment was carried out in a factorial fashion which consisted of six levels of parasite leaf filtrate concentrations $(\mathrm{K})$, namely 0 : $0 \%$ concentration, 1 : $20 \%$ concentration, 2 2: $\quad 40 \%$ concentration, 3: $60 \%$ concentration, 4: $80 \%$ concentration, and 5: $100 \%$ concentration. Also, there were controls and the replications were carried out five times within 72 hours of observation. 


\section{RESULTS AND DISCUSSION}

Based on the results of phytochemical tests, the acacia parasite contained alkaloids, flavonoids, saponins, triterpenoids, phenolics, and tannins. There was
$200 \mathrm{~mL}$ of filtrate produced from 326 grams of parasite leaves. The filtrate was then tested on the bagworms (Metisa plana) with several concentrations, namely $0 \%, 20 \%$, $40 \%, 60 \%, 80 \%$, and $100 \%$.

Table 1. The Results of Phytochemicals Test on Parasite Leaf Filtrate

\begin{tabular}{lll}
\hline $\begin{array}{c}\text { Phytochemicals } \\
\text { Test }\end{array}$ & \multicolumn{1}{c}{ Reagent } & \multicolumn{1}{c}{ Results } \\
\hline Alkaloids & Mayer & The orange precipitate $(+++)$ \\
& Wagner & Brown precipitate \\
& Deggendorf & White precipitate \\
Flavonoids & Mg $+\mathrm{HCl}_{\text {concentrated }}+$ ethanol & Red color(+++) \\
Saponin & Distilled Water & $\begin{array}{l}\text { The presence of stable } \\
\text { foam(+) }\end{array}$ \\
& & Purple to blue/green \\
Steroids & Libermann-Burchard & Brownish red (+) \\
Triterpenoid & Chloroform $+\mathrm{H}_{24} \mathrm{SO}_{\text {concentrated }}$ & White precipitate (++) \\
Phenolic & NaCl $10 \%+$ Gelatin $1 \%$ & Purple blackish (+++) \\
Tanin & $\mathrm{FeCl}_{3} 1 \%$ & \\
\hline
\end{tabular}

Table 2. The Percentage of Bagworms' Mortality on Day One

\begin{tabular}{cc}
\hline Concentration & Average Individual Mortality \\
\hline $0 \%$ & $0.0 \pm 0.00^{\mathrm{a}}$ \\
$20 \%$ & $36.0 \pm 16.73^{\mathrm{b}}$ \\
$40 \%$ & $60.0 \pm 14.14^{\mathrm{c}}$ \\
$60 \%$ & $88.0 \pm 10.95^{\mathrm{d}}$ \\
$80 \%$ & $84.0 \pm 8.94 \mathrm{~d}$ \\
$100 \%$ & $88.0 \pm 10.95^{\mathrm{d}}$ \\
\hline
\end{tabular}

Note: The letters $a, b, c$, and d show the notation of differences and effectiveness of the treatments on each concentration.

The results of the bioinsecticide test of acacia parasite leaf filtrate on the bagworms with concentrations of $0 \%, 20 \%, 40 \%$, $60 \%$, and $100 \%$ showed significant results. This was proven by the results of the ANOVA test with the

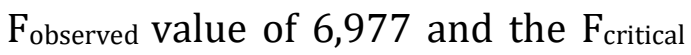
value of 2.76. Then, it can be stated that the $\mathrm{F}_{\text {observed }}>\mathrm{F}_{\text {critical }}$ which means
$\mathrm{H}_{0}$ was rejected and $\mathrm{H}_{1}$ was accepted. It can be concluded that there was an influence of acacia parasite filtrate toward the mortality of bagworms. Based on the Duncan test, it was known that the concentration of $60 \%$ and $100 \%$ showed the most effective results compared to other treatments. 
Biosfer: Jurnal Tadris Biologi, 11 (1) (2020) 58 - 65

Makmun Murod, Cicik Ainurrohmah, Hayatin Nufus

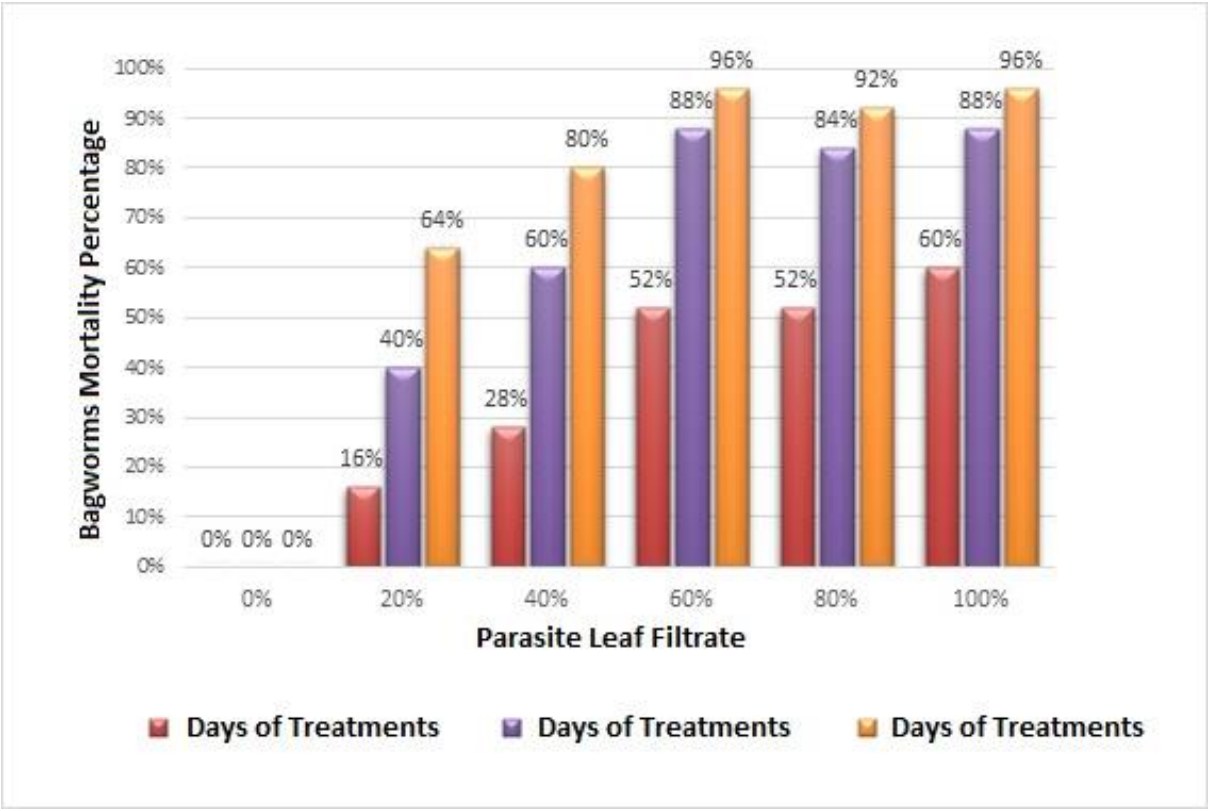

Figure 1. The Dynamics of Bagworm Mortality Rates for 3 Days

Based on the testing, the parasite leaf filtrate on affected the mortality of the bagworms. The dynamics of bagworm mortality rates during the research activities were at the concentrations of $0 \%, 20 \%, 40 \%$, $60 \%, 80 \%$, and $100 \%$.

Figure 1 shows the increase in the percentage of bagworm mortality from the first day to the third day. The highest bagworm mortalities were obtained at $100 \%, 60 \%$, and $80 \%$ concentrations with the mortality percentage of $96 \%, 96 \%$, and $92 \%$. The lowest mortality rate was found in filtrate treatment with a concentration of $0 \%$ which resulted in a $0 \%$ mortality percentage. In the treatment with the $60 \%$ of filtrate concentration, the mortality of the bagworms was quite high because the toxic content found in the filtrate was able to affect the bagworms. The concentration was increased day by day resulted in a higher active content of the biopesticide. The secondary metabolite contents in the parasite filtrate have the potential as the toxic ingredients for the bagworm which causes death. The right concentration of plant-based insecticides ingested by insects can directly cause insect mortality whereas at non-lethal concentrations only affect behavior and physiology (F. Lestari \& Darwiati, 2014) The data of observation on the cause of mortality of bagworms was supported by the results of the phytochemical test which shows that the parasite leaf filtrate contained secondary metabolites in the form of Alkaloids, flavonoids, saponins, triterpenoids, phenolics, and tannins. The presence of secondary metabolite compounds that were sprayed on the leaves caused the leaves to taste bitter with a pungent odor, causing the bagworms to unable to eat and die. Based on research by (Sundaryono, 2011), the flavonoids in parasite leaf affect the bodyweight because the content of these toxic compounds can affect the metabolism of living things. Also, tannin is a polyphenol active compounds that can bind the proteins by creating a bitter sense which influences the level of consumption (Ningsih, dkk. 2013). Based on the results of the study conducted by (Ahmad dkk., 2019), the plant-based insecticides' toxin serves 
as antifeedant and repellent that disrupts the physiological process and inhibits larval development. This can occur because there is a process of chemical compound activity due to the presence of enzymes, antibiotic proteins, and toxic compounds that can damage the nervous system, respiratory system, and digestive systems of the insects.

\section{CONCLUSIONS AND SUGGESTIONS}

The results of the phytochemical test showed that the parasite leaves contained alkaloids, flavonoids, saponins, triterpenoids, phenolics, and tannins. It was also found out that the parasite leaf filtrate showed an effect on the mortality of bagworms. The most effective dosages to be applied were $80 \%, 60 \%$, and $100 \%$ concentrations. Further research needs to be carried out to further improve the performance of parasite leaf filtrate as a natural pesticide. More research needs to be done to develop other types of natural and environmentally friendly pesticides to avoid environmental pollution. This research is expected to be used as a reference for further research.

\section{REFERENCES}

Affandi, A., Hamim, H., \& Nurmauli, N. (2014). Pengaruh Pemupukan Urea dan Teknik Defoliasi pada Produksi Jagung (Zea mays L.) Varietas Pioneer 27. Jurnal Agrotek Tropika, 2(1).

Ahmad, N., Yanuwiadi, B., Retnaningdyah, C., \& Hakim, L. (2019). Diversity and Conservation Status of Fish in The Water of Rolak Songo Dam, Mojokerto District East Java Indonesia. IOP Conference Series: Earth
Environmental Science, 391(1), 012077.

Anita, A., Khotimah, S., \& Yanti, A. H. (2014). Aktivitas antibakteri ekstrak daun benalu jambu air (Dendropthoe pentandra (L.) Miq) terhadap pertumbuhan Salmonella typhi. Jurnal Protobiont, 3(2), 268-272.

Candra, D., Santi, I. S., \& Kristalisasi, E. N. (2018). Efektifitas Penggunaan Bacillus Thuringiensis Dan Lamda Sihalotrin Pada Ulat Api. JURNAL AGROMAST, 3(1).

Efendi, S., Febriani, F., \& Yusniwati, Y. (2020). Inventarisasi Hama Kelapa Sawit (Elaeis Guineensis Jacq.) Pada Daerah Endemik Serangan Di Kabupaten Dharmasraya. AGRIFOR, 19(1), 1-10.

Haryati, Y., \& Nurawan, A. (2017). Peluang pengembangan feromon seks dalam pengendalian hama ulat bawang (Spodoptera exigua) pada bawang merah. Jurnal Penelitian dan Pengembangan Pertanian, 28(2), 72-77.

Kurniawan, B., Kurnia, Y., Husna, I., Rahmat, A., Umam, R., \& Andriana, B. B. (2020). Utilization of Stem Bark and Leaves of Kluwih (Artocarpus Altilis Park) as an AntiMosquito Repellent: A Case Study of Total Mosquito Mortality (Anopheles Sp). Indonesian Journal of Science \& Technology, 5(3), 421-439.

Latumahina, F., Musyafa, M., Sumardi, S., \& Putra, N. S. (2015). 
Respon Semut Terhadap Kerusakan Antropogenik Dalam Hutan Lindung Sirimau Ambon (Ants Response to Damage Anthropogenic in Sirimau Forest Ambon). Jurnal Manusia dan Lingkungan, 22(2), 169-178.

Lestari, F., \& Darwiati, W. (2014). Uji efikasi ekstrak daun dan biji dari tanaman suren, mimba dan sirsak terhadap mortalitas hama ULAT GAHARU. Jurnal Penelitian Hutan Tanaman, 11(3), 165-171.

Lestari, M. S., Himawan, T., \& Retnowati, R. (2016). Potensi ekstrak Piper methysticum (Piperaceae) sebagai insektisida botani untuk pengendalian hama Plutella xylostella. Sains \& Matematika, $3(1)$.

Lukmana, M., \& Elafia, N. (2017). Tingkat Serangan Hama Ulat Api Pada Tanaman Kelapa Sawit (Elaeis Guineensis Jacq.) Fase Belum Menghasilkan Di Pt Barito Putera Plantation. AGRISAINS, 3(01), 18-22.

Nahdi, M. S. (2008). Konservasi Ekosistem dan Keanekaragaman Hayati Hutan Tropis Berbasis Masyarakat. Jurnal Kaunia, 4(2), 159-172.

Nugraheni, E., \& Pangaribuan, N. (2008). Pengelolaan Lahan Pertanian Gambut Secara Berkelanjutan. Universitas Terbuka, Tangerang Selatan Universitas Pajajaran, 73-88.

Nugroho, A. W. (2017). Konservasi Keanekaragaman Hayati
Melalui Tanaman Obat Dalam Hutan Di Indonesia Dengan Teknologi Farmasi: Potensi Dan Tantangan. Jurnal Sains dan Kesehatan, 1(7), 377-383.

Nurjanah, S. R., Nurazizah, N. N., Septiana, F., \& Shalikhah, N. D. (2019). Peningkatan Kesehatan Masyarakat Melalui Pemberdayaan Wanita dalam Pemanfaatan Pekarangan dengan Tanaman Obat Keluarga (TOGA) di Dusun Semawung. Community Empowerment, 4(1), 20-25.

Priono, S. H. (2013). Pengaruh Komposisi Media Tanam Terhadap Pertumbuhan Stek Batang Tanaman Ara (Ficus carica L.). Skripsi. Departemen Agronomi Dan Hortikultura, Fakultas Pertanian, Institut Pertanian Bogor.

Purwantini, T. B. (2016). Potensi dan prospek pemanfaatan lahan pekarangan untuk mendukung ketahanan pangan. Forum Penelitian Agro Ekonomi, 30(1), 13-30.

Ridhwan, M. (2012). Tingkat Keanekaragaman Hayati dan Pemanfaatannya di Indonesia. Jurnal Biology Education, 1(1).

Saenong, M. S. (2016). Tumbuhan Indonesia potensial sebagai insektisida nabati untuk mengendalikan hama kumbang bubuk jagung (Sitophilus Spp.). Jurnal Penelitian dan Pengembangan Pertanian, 35(3), 131-142.

Santosa, S. J. (2013). Pengendalian Ulat Daun Sawi (Crocidolomia 
binotalis Zell.) dengan Insektisida Organik. Innofarm: Jurnal Inovasi Pertanian, 10(1).

Sembiring, N., Sembiring, N., Tarigan, M. U., \& Lisnawit, L. (2013). Tingkat Serangan Ulat Kantong Metisa Plana Walker (Lepidoptera: Psychidae) Terhadap Umur Tanaman Kelapa Sawit (Elaeis Guineensis Jacq.) Di Kebun Matapao PT. Socfin Indonesia. Jurnal Agroekoteknologi Universitas Sumatera Utara, 1(4), 95949.

Soesatrijo, J. (2018a). Efektivitas Ekstrak Akar Tuba (Derris elliptica) sebagai Bioinsektisida Ulat Kantung (Metisa plana) di Perkebunan Kelapa Sawit. Jurnal Citra Widya Edukasi, 10(2), 117124.

Soesatrijo, J. (2018b). Efektivitas Ekstrak Akar Tuba (Derris elliptica) sebagai Bioinsektisida Ulat Kantung (Metisa plana) di Perkebunan Kelapa Sawit. Jurnal Citra Widya Edukasi, 10(2), 117124.

Soetopo, D., \& INDRAYANI, I. (2015). Status Teknologi dan Prospek Beauveria bassiana Untuk Pengendalian Serangga Hama Tanaman Perkebunan. Perspektif, 6(1), 29-46.

Sopi, I. I. P. B., \& Tallan, M. M. (2019). Kajian beberapa tumbuhan obat yang digunakan dalam pengobatan malaria secara tradisional.
Styarini, D., Zuas, O., \& Hamim, N. (2011). Validation and uncertainty estimation of analytical method for determination of benzene in beverages. Eurasian Journal of Analytical Chemistry, 6(3), 159-172.

Sundaryono, A. (2011). Uji aktivitas senyawa flavonoid total dari Gynura segetum (lour) terhadap peningkatan eritrosit dan penurunan leukosit pada mencit (Mus musculus). EXACTA, 9(2), 8-16.

Susanto, A., Purba, R. Y., \& Prasetyo, A. E. (2010). Hama dan penyakit kelapa sawit. Pusat Penelitian Kelapa Sawit (PPKS), Medan.

Uji, T. (2010). Keanekaragaman Jenis Benalu Pemarasit Pada Tanaman Di Kebun Raya Baturraden Dan Sekitarnya. Jurnal Teknologi Lingkungan, 11(2), 205-211.

Utami, S., \& Kurniawan, A. (2019). Hama penting pada tegakan hutan dan teknik pengendaliannya di KHDTK Kemampo, Sumatera Selatan. Prosiding Seminar Nasional Perhimpunan Entomologi Indonesia (PEI) Cabang Palembang, 1(1), 404-414.

Wahyuni, M., \& Sinaga, M. A. (2017a). Efektivitas Pengendalian Hama Ulat Kantung (Metisa plana) Pada Tanaman Kelapa Sawit (Elaeis guineensis Jacq) Dengan Sistem Injeksi Batang Di Kebun Tanjung Garbus Pt. Perkebunan Nusantara II. Jurnal Agro Estate, 1(2), 104110. 
Wahyuni, M., \& Sinaga, M. A. (2017b). Efektivitas Pengendalian Hama Ulat Kantung (Metisa Plana) Pada Tanaman Kelapa Sawit (Elaeis Guineensis Jacq) Dengan Sistem Injeksi Batang Di Kebun Tanjung Garbus Pt. Perkebunan Nusantara II. Jurnal Agro Estate, 1(2), 104110.

Winarni, B., Alex, T., Lahjie, A. M., \& Ruslim, Y. (2018). Analisis Produksi Dan Finansial Pengusahaan Tengkawang Oleh Rakyat di Kalimantan Barat Production and Financial Analysis of Tengkawang Cultivation by People in West Kalimantan. Jurnal Hutan Tropis, 5(3), 236-243.
Wongkar, J. S., Runtuwene, M. R., \& Abidjulu, J. (2015). Uji Toksisitas Ekstrak Daun Benalu Langsat (Dendrophthoe petandra (L) Miq) dengan Metode Brine Shrimp Lethality Test (BSLT) LC50. Jurnal MIPA, 4(2), 157160. 